Mads Thau*

\title{
The Demobilization of Class Politics in Denmark: The Social Democratic Party's Group-Based Appeals 1961-2004
}

https://doi.org/10.1515/wps-2018-0011

\begin{abstract}
In Denmark, as in other Western European countries, the working class does not vote for social democratic parties to the same extent as before. Yet, what role did the social democratic parties themselves play in the demobilization of class politics? Building on core ideas from public opinion literature, this article differs from the focus on party policy positions in previous work and, instead, focuses on the group-based appeals of the Social Democratic Party in Denmark. Based on a quantitative content analysis of party programs between 1961 and 2004, I find that, at the general level, class-related appeals have been replaced by appeals targeting non-economic groups. At the specific level, the class-related appeals that remain have increasingly been targeting businesses at the expense of traditional left-wing groups such as wage earners, tenants and pensioners. These findings support a widespread hypothesis that party strategy was crucial in the decline of class politics, but also suggests that future work on class mobilization should adopt a group-centered perspective.
\end{abstract}

Keywords: class politics; demobilization; Social Democratic Party; Denmark.

\section{Introduction}

Social class has long been a key concept in political science research. In a number of Western European countries, including Denmark, the party systems used to be class-based (Lipset and Rokkan 1967). However, it is also well established that social class has lost much of its political relevance since the 1960s. This applies not least to class politics in its traditional form: the working class does not vote for social democratic parties to the same extent as before (Lipset 1981; Franklin et al. 1992; Inglehart 1997; see Dalton 2014 for a review). This holds for Western Europe, generally, but the pattern has been particularly clear in the UK and in

*Corresponding author: Mads Thau, VIVE - The Danish Center for Social Science Research, Aarhus, Denmark, e-mail: math@vive.dk 
Scandinavian countries such as Denmark (Knutsen 2006). Yet, why has class voting declined?

Most recent work suggest that the explanation should be found in the behavior of the political parties themselves (Oskarson 2005; Elff 2009; Evans and Tilley 2012; Evans and de Graaf 2013; Heath 2015). In short, social democratic parties were key in the mobilization of the working class, and the very same parties are thought to have played a decisive role in its demobilization (Przeworski and Sprague 1986). In this article, I focus on Denmark's traditional workingclass party and examine whether the Social Democratic Party is still making appeals to class-related groups, or whether its appeals have increasingly been targeting other social categories or groups. Whereas previous work has examined class demobilization by analyzing the policy-based appeals of political parties, I instead focus on parties' group-based appeals. I do this because an extensive body of public opinion literature questions whether parties' policy statements actually matter to voters (Converse 1964; Achen and Bartels 2016). At the same time, this literature shows that voter decision-making is, at least partly, based on group affiliation and social identity and is therefore susceptible to the groupbased appeals of political parties (Campbell et al. 1960; Butler and Stokes 1969; Conover 1988; Nelson and Kinder 1996; Kinder and Kam 2009; Achen and Bartels 2016). This group perspective is in many ways closer to how the cleavage model traditionally described the mobilizing role of political parties (Lipset and Rokkan 1967; Przeworski 1985: p. 101; Bartolini and Mair 1990: p. 205; see Heath 2015: p. 190).

Denmark is a good place to examine the demobilization of class politics from a group perspective. On the one hand, Denmark is a typical case on the development of Western European politics. Like other leftist and social democratic parties, the Social Democratic Party in Denmark has had to rethink their voter base as societal change reduced the size of the working class and led to a general shift in voters' issue priorities (e.g. Kosiara-Pedersen and Bille 2004). On the other hand, the Danish case seems deviant in the policy-centered theoretical model. We know that class voting has been steadily declining in Denmark; but the Social Democratic Party has not clearly changed its economic policy position just as voters perceive the party's position as relatively stable (Hobolt 2013). The Danish case thus seems particularly useful in examining an alternative theoretical explanation (Seawright and Gerring 2008: p. 302).

I examine the Social Democratic Party's group-based appeals using a quantitative content analysis of party programs published in the 1960s, 1980s and 2000s. Among other things, the results show that the Social Democratic Party has toned down its historical ties to the working class and other traditional voter groups, while, at the same time, both businesses and a number of middle-class 
professional groups have been consistent targets in the appeals. At a more general level, the party has also increasingly emphasized non-economic groups - such as children, the elderly and the sick - at the expense of economic groups as such. Overall, these findings suggest that the Social Democratic Party in Denmark changed its group-centered mobilization strategy in line with the catch-all thesis (Kirchheimer 1966) in an effort to expand its electoral base.

\section{The Demobilization of Class Politics}

Although the trend in class voting was heavily debated in comparative electoral research in the 1990s, a recent consensus seems to have spread that the relationship between social class position and vote choice has waned (Knutsen 2007: p. 464). Consequently, the focus in the literature has also shifted from describing the developments to explaining them: why has class voting declined?

There are two broad perspectives on this (Evans 2000). According to the bottom-up perspective, the explanation for declining class voting is that the societal class structure has become more fluid. Fewer voters now clearly belong to any one particular class, and thus social classes have become internally heterogeneous and the differences between them have dwindled (see Dalton 2014: Chapter 8). As a consequence, the classes have also become increasingly similar in terms of party preferences. In this perspective, political change is assumed to result directly from societal change. The political parties do not play an active role, but are seen as passive spectators to the decline of class politics. According to the top-down perspective, however, the explanation lies with the political parties themselves. Sartori (1997: p. 169) expresses this logic as follows: “The party is not a consequence of the class. Rather, and before, it is the class that receives its identity from the party." In other words, class politics has not simply disappeared; it has been politically demobilized.

However, that does not mean that social change is without significance. The traditional, mainstream parties - social democratic parties in particular - have had to rethink their electoral base and broaden out the appeal in order to maintain their size and influence (Przeworski and Sprague 1986; Kitschelt 1994). Just as religiously based parties have had to look towards new voter groups in the face of secularization, social democratic parties have had to look beyond workers because the working class has become smaller (Best 2011). In this sense, social change is important in the top-down perspective. Still, the focus is on how parties react to changes in the electoral market: in the end, it is the mobilization strategies of the parties, which are seen as most crucial to the development of class politics (Evans 2000: p. 410). 
Recent empirical research has supported the top-down perspective. Both case studies and comparative research have found empirical evidence that political parties play a key role (Oskarson 2005; Elff 2009; Evans and Tilley 2012; Heath 2015; Evans and Tilley 2017). For example, the most comprehensive survey thus far concludes that class voting depends on the "political choice" that parties give to voters (Evans and de Graaf 2013). However, this recent line of research can also be criticized on theoretical grounds. The seminal literature considered class politics to be a collective phenomenon. It emphasized voters' social identities and the role of social democratic parties in mobilizing the working class as a group (Lipset and Rokkan 1967; Przeworski 1985: p. 101; Bartolini and Mair 1990: p. 205). As Dalton and Wattenberg (1993: p. 196) argue, group-based voting was upheld by the group-based appeals of competing parties. But when recent research has examined the demobilization of class politics, it has focused on parties' policy positions. As Heath (2015: p. 190) points out, this seems to build on a micro-level theory about voters as individuals motivated by policy preferences rather than a theory about social identity and group representation. The group-centered perspective has apparently been lost.

\section{A Group Perspective on Demobilization}

Theoretically, there are good reasons to study working class demobilization from a group perspective. Firstly, the literature on public opinion and attitude formation raises questions about the "microfoundation" of the policy-centered theoretical model. As Converse (1964) pointed out more than 50 years ago, only few voters have genuine and informed views on most political issues. The ordinary voter does not walk around with set preferences for given policies. Moreover, when people actually express political preferences, these often turn out to be context-dependent and unstable (Achen and Bartels 2016). Nevertheless, the assumption in most recent research seems to be that class demobilization is driven by an increasing mismatch between the policy preferences of workingclass voters and the policies offered by social democratic parties (e.g. Evans and Tilley 2012: p. 141).

Secondly, the public opinion literature also points out that group affiliation and social categorization play a key role in voter decision-making (Campbell et al. 1960: Ch. 12 and 13; Converse 1964; Butler and Stokes 1969; Conover 1988; Popkin 1994: Ch. 3; Achen and Bartels 2016). For ordinary citizens, both political information processing and political decision-making are strongly influenced by group thinking. This social categorization is a basic way that voters simplify the 
complex and abstract world of politics (Popkin 1994: p. 218). The best example is the representational ties between different political parties and social groups. Often, voters see certain parties as representatives of certain groups (Dalton 2014: p. 31). This also applies in Denmark, where voters (still) see the Social Democratic Party as representing the working class and low-income groups, whereas the main right-wing party, the Liberals, is associated with the upper class and high-income groups (Stubager 2009; Hjort 2017).

Voters actively use this delineation in their vote choices. As Miller et al. (1991) explain, a voter's party preference depends partly on that voter's affiliation with a particular social group and partly on that group's tie to a particular political party. This two-step model corresponds to the way class politics was conceptualized in the seminal literature. For example, Butler and Stokes (1969: pp. 85-87) describe class voting in this exact way: (i) a voter belongs to a given class, (ii) and a given class is tied to a party. A group-centered perspective on class demobilization focuses on the latter step, and examines how social democratic parties themselves have attempted to reshape their image as class representatives.

What exactly are social democratic parties doing to shape their own image, and what does this mean for the relationship between individual class position and vote choice? People's perceptions of party-class ties have a long history, which often date back to the origins of party systems (Lipset and Rokkan 1967). Therefore, the content of these historical ties is difficult to change. On the other hand, a party can tone down or highlight its class image through its political communication. As mentioned above, Dalton and Wattenberg (1993: p. 196) have pointed out that group-based appeals played an important role in mobilizing class politics. We should expect that group-based appeals play a similar role in the demobilization of class politics. It is unlike that social democratic parties will be able to change their image as working class representatives in the attempt to broaden their appeal, but they can influence just how salient this image is to voters. Indeed, a number of studies on priming suggest that group-based appeals are especially useful in this regard, as they can activate or deactivate group thinking in voter decision-making (Nelson and Kinder 1996; Kinder 1998; Kinder and Kam 2009).

In this article, I define a group-based appeal as an explicit statement that links a political party with a given group category. Group-based appeals are found in the communications of political parties (e.g. party programs, speeches or TV debates) and thus consist of: (i) a party, (ii) a group category and (iii) the relationship between the party and the group. It is the change and stability in how social democratic parties use such appeals that this article focuses on. 


\subsection{Theoretical Expectations}

If a group perspective is to contribute to our understanding of class demobilization, we should expect that the Social Democratic Party has unequivocally downplayed its ties to the working class. Although this article does not offer a test of whether group-based appeals condition class voting, the changes at the party level should at least correspond to the changes seen at the voter level. The Danish case challenges the policy-centered theoretical model in other studies precisely because class voting in Denmark has waned without a corresponding change in economic policies of the Social Democratic Party (Hobolt 2013).

Overall, the group-based appeals of the Social Democratic Party should reflect its attempt to expand the electoral base in the light of a changing electoral market. The transformation of the industrial economy has meant that the working class has become ever smaller during the second half of the 20th century, while the middle class has grown (Crouch 2008). Thus, the voting potential is declining for the working class and increasing for the middle class. From a partystrategic perspective, this means that the working class has become less attractive for the social democratic parties, and the middle class more so (Best 2011: $\mathrm{p}$. 282). This way, societal change has undermined the usefulness of a traditional strategy based on working class mobilization. At the same time, however, societal change has also opened up some new possibilities. Over time, voters have gained new issue priorities, such as immigration, gender equality, environment and criminal justice (Inglehart 1997; Andersen and Borre 2003). The emergence of the "new politics" agenda has politicized many new group categories that seem obvious targets in parties' group-based appeals - especially for parties whose traditional base is shrinking. On the one hand, the electoral market incentives thus "push" the social democratic parties away from traditional voter groups, while, on the other hand, they "pull" them towards a growing middle class as well as other newly politicized groups.

We should therefore expect to see a general shift in group-based appeals, where ties to economic groups as such are downplayed, while ties to non-economic groups are highlighted. As known from the party competition literature, electoral appeals, agenda setting and political attention are relative phenomena (e.g. Budge and Farlie 1983): just as parties cannot focus on all issues at once, they can also not focus on all groups. Emphasizing some will inevitably mean deemphasizing others. Even if economic group categories are still relevant targets to the Social Democratic Party, the focus on non-economic groups should imply a relative de-emphasis of economic groups.

We should also expect that workers, as a specific group category, are deemphasized in the Social Democratic Party's group-based appeals, because 
socio-economic change have made the working class smaller. The same should apply to group categories like wage earners or trade unions, which voters may see as synonyms for workers, as well as other group categories such as the lowincome groups and pensioners, which are not directly related to the working class, but were part and parcel of the social democratic voter base. If such historically associated groups were targeted, voters may be reminded of the working class image of the Social Democratic Party, even if workers were not mentioned. Perceptions of party-class ties are still widespread and the Social Democratic Party has strong incentives to avoid its historical class image becoming salient among voters, as this would undermine its attempt to broaden the voter base. If a political party is perceived as "the working class party," it cannot also appear to be the party for the middle class or business. Given the transformation of the industrial economy, we should expect the Social Democratic Party to try to broaden its appeal beyond traditional class divisions.

\section{Research Design and Data}

To study the demobilization of class politics from a group perspective, I concentrate on the Social Democratic Party in Denmark and analyze a new dataset consisting of 1700 group-based appeals found in a quantitative content analysis of its party programs in the 1960s, 1980s and 2000s. There are two types of party programs in Denmark and both are used as sources. The principle platform outlines a party's ideological vision and is rarely updated (called Principprogram in Danish). The Working Program, on the other hand, lays out specific policy proposals for a shorter period and is usually more comprehensive (called Arbejdsprogram in Danish). Even though the working programs do not always follow the election cycle, they are reminiscent of the election manifestos known from other countries such as the UK, the Netherlands or Norway. It is not all parties in Danish party system have a tradition of adopting and publishing party programs, but the Social Democratic Party has made use of both types for more than 100 years.

For the purpose of this article, party programs have a number of advantages. Firstly, they represent the party as a unitary actor, which is an obvious advantage to any study of party-level behavior (Helbling and Tresch 2011: p. 176). Secondly, party programs are particularly suitable for over-time analyses, because they have had the same basic format and function throughout the years (Green-Pedersen 2011: p. 63). Their function is, partly, to coordinate the internal party line and, partly, to present the party's policies to voters, the media, and society in general. In line with existing research, I am not interested in the party programs as such, but rather in the party strategic behavior that we can measure by analyzing their 
content (Budge et al. 2001). It is thus not the assumption that the average citizen will read the programs (although some may), but that the party programs provide a snapshot of which groups the Social Democratic Party targeted in given time periods. Party programs have been chosen in favor of the campaign material that other studies have previously used as sources (Budge et al. 2001) because the quality of this campaign material is questionable (see Hansen 2008). Often, this material consists of just flyers and posters, and in some years, the source material for all the parties contains as few as 50 sentences. Party programs do not give as fine-meshed timeline as the election campaign material, but they form a more solid text source.

A third advantage is the long history of the party programs, which provides fitting coverage of the period during which the societal changes pointed out in the literature took place. Before the 1960s, the party systems in Denmark and other countries were still "frozen" and class-based (Lipset and Rokkan 1967), while class voting stabilized at a low level in the late 1990s (Knutsen 2006). As a consequence, the content analysis in this article covers three principle platform publications in 1961, 1977 and 2004, respectively, as well as three working programs in 1961, 1980 and $2001 .^{1}$

As described in the codebook (supplementary material in Danish), the coding of party programs took place using group-based appeals as the unit of analysis. The unit consists of a "subject" (i.e. the Social Democratic Party), an "object" (i.e. a group category) and a "relationship" (i.e. whether party and group are associated or dissociated). Previous research has used this same methodology to code policy-based appeals (Kriesi et al. 2008). The main difference is whether the "object" refers to a policy, as in Kriesi et al., or a group, as it does here. Based on the codebook and 2 weeks of training, two research assistants read the party programs line-by-line and identified 1702 group-based appeals in total. An intercoder reliability test indicates that this was done reliably (Krippendorff's alpha $=0.87$; see Krippendorff 2004).

The group-based appeals were coded on a number of variables that, besides the year, had to do with the party, the group and their relation. Since the purpose of this article is to examine how the Social Democratic Party's "selective emphasis" of different groups evolve, the analysis primarily uses those cases where the party associates itself with a group. This leaves this part of the analysis with 1467

1 The Social Democratic Party has published its principle platform six times: in 1876, 1913, 1961, 1977, 1992, and 2004. The working programs have been published more often, with 21 releases from 1888 to 2000 . I selected the sample of six party programs with the purpose of obtaining a sufficient but also even coverage across the theoretically relevant period from the 1960 s to the 2000s. 
group-based appeals. ${ }^{2}$ In a sub-analysis of the Social Democratic Party's ties to business, however, I also draw on those group-based appeals where the two are dissociated, or where the group-party relation is coded as neutral.

The group itself has been coded on two main categories and several subcategories. The main categories distinguish whether the group is economic or noneconomic. Social class can be understood in many ways, but class is traditionally considered as having to do with economic capital or resources (Hout 2008: p. 26). The group is therefore coded as economic if it explicitly refers to: (i) financial resources (e.g. the wealthy), (ii) a labor market position (e.g. workers), or (iii) a profession (e.g. teachers). In all other cases, the group is coded as non-economic. If classified as economic, the group is further coded on a number of subcategories such as wage earners, businesses, pensioners or unemployed. If the group is classified as non-economic, it is coded on subcategories such as immigrants, women, the ill or the low-educated. ${ }^{3}$ In total, the group-based appeals are coded on 23 economic and 21 non-economic subcategories, which all figure in Tables 1 and 3 in the results section below. The codebook in the supplementary material describes these groups in more detail. Intercoder reliability tests of the variables used in the results section below indicate that here, too, the coding was highly reliable (Krippendorff's alpha $=0.85$ for the lowest-scoring variable).

\section{The Social Democratic Party's Group-Based Appeals from 1961 to 2004}

\subsection{Economic and Non-Economic Groups}

Are the Social Democratic Party still appealing to economic groups? Or are other groups now at the heart of its group-based appeals? We know that voters increasingly prioritize non-economic issues in politics, and that the emergence

2 The results do not change if I also include those appeals where the Social Democratic Party dissociates itself from a group $(n=62)$ or where the tie between party and group cannot be determined or is neutral $(n=156)$.

3 Level of education is sometimes taken to indicate individual class position (see, for example, Harrits 2014). In the differentiation between economic and non-economic groups, however, education groups seem to fit the latter best. Although education may partly determine an individual's occupation, income or wealth, education does not constitute an economic position in itself. I also note that results do not depend on whether the group-based appeals targeting education groups are coded as economic or non-economic, because these appeals are few altogether. 
of the "new politics" has politicized new groups that seek political representation (Franklin et al. 1992; Mair 2013). Therefore, we should also expect the Social Democratic Party to focus on non-economic groups at the expense of the economic ones. I address this, and other, questions about change and stability in group-based appeals by looking at the percentage of all group-based appeals that target specific group categories.

Figure 1 shows how the Social Democratic Party's appeals have been distributed across economic and non-economic groups over time in the two types of party programs analyzed. It is clear that are economic groups are targeted less and non-economic more over time. Looking at the working programs, about half (51\%) of all group-based appeals targeted economic groups in 1961. This figure dropped markedly towards 1980 (37\%), and, in 2000, only one-fifth (20\%) of the appeals targeted an economic group. The picture is largely the same if we look to the principle platform, although the major drop here occurred between 1977 and 2004. Just 4 coded appeals, or 3\%, in the Social Democratic Party's latest principle platform from 2004 were targeting economic groups, according to the relatively broad definition used.

This suggests that the Social Democratic Party adjusted its electoral strategy, as Denmark, like Western Europe in general, underwent societal changes, which meant that voters got other social group affiliations and different issue priorities.

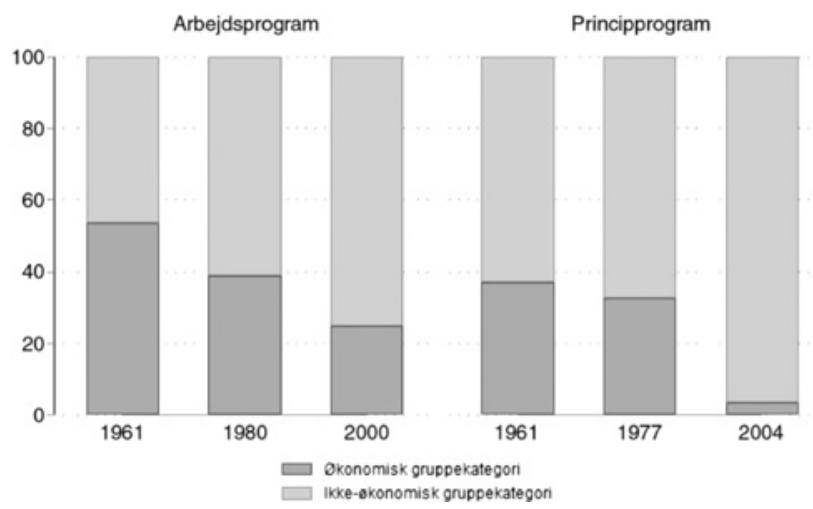

Figure 1: How the Social Democratic Party Targets Economic (Dark Gray) and Non-Economic Groups (Light Gray) (Percentages).

Note: The figure shows the percentage of all group-based appeals targeting economic and noneconomic group categories, respectively. Dark gray is economic group categories and light gray is non-economic group categories. Left-hand panel is the working programs and right-hand panel is the principle platform publications. Source: The Social Democratic Party's working program and principle platform, 1961-2004. 


\subsection{Economic Group Categories}

What about specific target groups? Considering the decline of the working class and the growth of the middle class, social democratic parties have had strong incentives to downplay their working class image (Przeworski and Sprague 1986; Kitschelt 1994). But do we actually see the expected pattern? Table 1 shows the percentage of group-based appeals targeting each of the economic group categories. To ease presentation, this table collapses the working programs and the principle platforms so that group-based appeals found in the 1961 working program and the 1961 principle platform are presented together. The same applies to the 1977

Table 1: How the Social Democratic Party Targets Various Economic Subgroups (Percentages).

\begin{tabular}{|c|c|c|c|c|}
\hline & $1961 / 1961$ & $1977 / 1980$ & $2000 / 2004$ & Total \\
\hline Wage earners & 7.8 & 6.1 & 2.0 & 4.3 \\
\hline Businesses & 6.3 & 7.0 & 5.7 & 6.3 \\
\hline Low-income people & 4.2 & 1.4 & 1.1 & 1.6 \\
\hline Pensioners & 2.8 & 1.3 & 0.1 & 0.9 \\
\hline Farmers & 2.8 & 0.6 & - & 0.6 \\
\hline Students & 1.4 & - & 1.0 & 0.6 \\
\hline Trade unions & 0.7 & 2.4 & 0.3 & 1.2 \\
\hline Tenants & 0.7 & 1.4 & 0.1 & 0.8 \\
\hline School teachers & 0.7 & 0.5 & 0.7 & 0.6 \\
\hline Unskilled workers & 0.7 & 0.3 & - & 0.2 \\
\hline Public employees & 0.7 & 0.2 & 0.4 & 0.3 \\
\hline Homeowners & - & 1.8 & - & 0.8 \\
\hline Self-employed & - & 0.5 & 0.1 & 0.3 \\
\hline High-income people & - & 0.5 & - & 0.2 \\
\hline Childcare workers & - & 0.3 & 0.3 & 0.3 \\
\hline Private employees & - & 0.3 & 0.1 & 0.2 \\
\hline Unemployed & - & 0.2 & 1.0 & 0.6 \\
\hline Doctors & - & 0.2 & 0.9 & 0.5 \\
\hline Middle-income people & - & 0.2 & - & 0.1 \\
\hline Police officers & - & - & - & - \\
\hline Nurses & - & - & - & - \\
\hline Skilled workers & - & - & - & - \\
\hline Other (residual category) & 12.0 & 6.7 & 2.9 & 5.4 \\
\hline $\mathrm{N}$ economic groups & 58 & 199 & 118 & 375 \\
\hline $\mathrm{N}$ total & 142 & 625 & 700 & 1467 \\
\hline
\end{tabular}

The table shows the percentage of all group-based appeals targeting given subgroup categories. Notice that rows do not sum to 100 as the table concerns only economic group categories. Source: The Social Democratic Party's principle platform and working program, 1961-2004. 
principle platform and 1980 working program, while the 2000 working program and 2004 principle platform form a third time period.

Several results are worth highlighting. First, one may note that, in terms of salience, workers were never really a prominent reference group in the social democratic party programs. Less than $1 \%$ of the party's group-based appeals targeted workers at the peak of class politics in the 1960s, while the 2000 and 2004 party programs fails to mention workers at all. This is a surprising finding considering that Denmark is seen as a typical case on class-dominated politics (Green-Pedersen 2006; Knutsen 2006), and it contrasts with the rhetoric of the Labour Party in Britain, where worker references were about ten times as prevalent around the same time (Evans and Tilley 2017; Thau 2017).

On the other hand, we see that several other group categories - which were also part of the left-wing base and probably refer to some of the same people as workers - have been prominent target groups for the Social Democratic Party. In particular, wage earners (8\%) and low-income people (4\%) were quite frequently targeted in the 1960s, as were pensioners (3\%). Most importantly, however, these traditional target groups all change in a similar way: by the 2000s, they had all become less significant. Indeed, the Social Democratic Party only targeted wage earners in $2 \%$ of the group-based appeals in its most recent party programs. For low-income people and pensioners, the figures are about $1 \%$ and $0.1 \%$, respectively. Tenants and unions - groups that have also traditionally been associated with social democratic parties - also show the same downward trend from the 1980s to the 2000s.

Table 1 also shows that a number of middle-class professions seem to play an increasing role for the Social Democratic Party. Although the percentages are small, we see that school teachers, childcare workers and doctors have emerged as target groups over the years. In 2000 and 2004, the Social Democratic Party targeted a larger percentage of its group-based appeals at these three groups than at unions, tenants or pensioners. This suggests, as expected, that the Social Democratic Party has gradually downplayed its ties to the working class and other traditional groups, while at the same time it has broadening out its appeals to cross former class distinctions.

This becomes even clearer when looking at the traditional counterpart of the working class, big business. As Table 1 shows, contrary to the traditional core group categories, businesses represent a relatively stable target of the Social Democratic Party's appeals. About $6 \%$ of the group-based appeals referenced businesses in 1961, while 7\% did so in 1977 and 1980. And although the economic group categories diminished in general (see Figure 1), a solid 6\% of all groupbased appeals still targeted businesses in 2000 and 2004. In fact, businesses were by far the most prominent economic group category in the 2000s, almost 
three times as salient as wage earners, who were the most salient target group in the 1960s.

It is worth considering business more closely by looking at how the tie between the Social Democratic Party and business has changed over time. In addition to those appeals where the relation between party and group category is positive, I also look at those appeals where the relation is negative or neutral. Table 2 shows the percentage of business appeals that was coded as having a negative, neutral or positive relation between the Social Democratic Party and businesses, over the period studied. It appears that the Social Democratic Party has primarily associated itself with businesses in the 1960s, 1980s as well as the 2000s, at least in its party programs. But it is also clear that the party has become more closely tied to businesses than before. In the 1960s and 1980s, about half the business appeals were positive, while in the 2000s it was two-thirds. Furthermore, we see a marked decrease in how often the Social Democratic Party dissociates itself from businesses, particularly from the 1980s to the 2000s. Whereas the party distanced itself from businesses in one-third (32\%) of business appeals in 1977 and 1980 - a period where Denmark was characterized by economic uncertainty and high unemployment - it dissociated itself from businesses in only 10\% of its business appeals in 2000 and 2004.

Taken together, the evidence suggests that the Social Democratic Party has used its group-based appeals in an attempt to break previous class divisions and expand its voter base. Economic groups as such figure less in the group-based appeals of the Social Democratic Party, while non-economic groups figure more. Traditional or core groups have become less salient, while middle-class professions such as teachers, childcare workers and doctors have become increasingly salient. Businesses have been steadily targeted, even as economic groups have lost emphasis overall. And when the Social Democratic Party references business

Table 2: How the Relationship between the Social Democratic Party and Businesses Changes over Time (Percentages).

\begin{tabular}{lrrrr}
\hline & $1961 / 1961$ & $1977 / 1980$ & 2000/2004 & Total \\
\hline Dissociation/negative & 11.1 & 32.2 & 10.0 & 22.0 \\
Neutral & 38.9 & 18.9 & 23.3 & 22.6 \\
Association/positive & 50.0 & 48.9 & 66.7 & 55.4 \\
N & 18 & 90 & 60 & 168 \\
\hline
\end{tabular}

This table shows, in percentages, whether the relationship between Social Democratic Party and businesses is negative (dissociation), neutral, or positive (association). Source: The Social Democratic Party's principle platform and working programs 1961-2004. 
in its group-based appeals, it increasingly associates rather than dissociated itself with this group category.

\subsection{Non-Economic Group Categories}

If non-economic groups now play a more substantial role in the mobilization strategy of the Social Democratic Party, it seems only natural to ask which of the non-economic group categories have gained particularly emphasis. As a final step in the analysis, Table 3 therefore shows the percentage of group-based appeal targeting each of the non-economic group categories in the 1960s, 1980s and 2000s.

Table 3: How the Social Democratic Party Targets Various Non-Economic Subgroups (Percentages).

\begin{tabular}{|c|c|c|c|c|}
\hline & $1961 / 1961$ & $1977 / 1980$ & $2000 / 2004$ & Total \\
\hline Everyone & 30.3 & 22.4 & 34.6 & 29.0 \\
\hline Families & 4.9 & 5.0 & 3.4 & 4.2 \\
\hline Children & 4.2 & 9.0 & 13.3 & 10.6 \\
\hline Young people & 3.5 & 2.7 & 5.0 & 3.9 \\
\hline Urban residents & 2.8 & 1.3 & 0.4 & 1.0 \\
\hline The ill & 2.1 & 4.2 & 4.3 & 4.0 \\
\hline Rural residents & 2.1 & 1.0 & 0.6 & 0.9 \\
\hline Single people & 2.1 & 0.3 & 0.4 & 0.6 \\
\hline Parents & 1.4 & 2.2 & 2.4 & 2.3 \\
\hline Women & 0.7 & 4.6 & 1.3 & 2.7 \\
\hline Men & 0.7 & 2.2 & 0.4 & 1.2 \\
\hline Immigrants & - & 3.0 & 2.4 & 2.5 \\
\hline Elderly people & - & 2.7 & 4.7 & 3.4 \\
\hline Danish people & - & 0.8 & 1.0 & 0.8 \\
\hline Low-educated & - & 0.5 & 0.4 & 0.4 \\
\hline Patients & - & 0.2 & 0.6 & 0.3 \\
\hline Highly educated & - & - & - & - \\
\hline Girls & - & - & - & - \\
\hline Boys & - & - & - & - \\
\hline Religious groups & - & - & - & - \\
\hline Other (residual category) & 4.2 & 6.1 & 7.9 & 6.8 \\
\hline N non-economic groups & 84 & 426 & 582 & 1092 \\
\hline $\mathrm{N}$ total & 142 & 625 & 700 & 1467 \\
\hline
\end{tabular}

The table shows the percentage of all group-based appeals targeting given subgroup categories. Notice that rows do not sum to 100 as the table concerns only non-economic group categories. Source: The Social Democratic Party's principle platform and working program, 1961-2004. 
I will highlight three points from the results in Table 3. First, we see that when the Social Democratic Party emphasizes non-economic groups, the catchall category "everyone" is clearly the most frequently used throughout the entire period. Besides the term "everyone," this category covers terms such as "voters," "people" and "citizens." This is obviously a broad and inclusive category, but the appeals coded here share the characteristic that no one really falls outside the category. Who would not fit the term "people"? About 30\% of all group-based appeals were targeting "everyone" in the 1960s. In the 1980s, it was about $22 \%$ and in the 2000s, it was almost 35\%. Although Przeworski (1985) has argued that social democratic parties and conservative parties generally differ in that the former focus on specific (class) groups, while the latter on broader categories, the results presented here indicate that the Social Democratic Party in Denmark has always focused on broad, inclusive voter appeals.

Second, we see that the social group categories that comparative political research often focus on as alternatives to class-centric party competition do not play a decisive role in the electoral strategy of the Social Democratic Party (e.g. Lipset and Rokkan 1967; Brooks et al. 2006). Our well-theorized group categories did not replace wage earners and low-income groups in the Social Democratic Party's group-based appeals. For example, with respect to the center-periphery cleavage, we see that while $3 \%$ and $2 \%$ of the group-based appeals targeted urban and rural residents in the 1960 s, only about $0.5 \%$ did so in the 2000 s. Likewise, although the salience of gender equality was apparent in the 1980s, it gradually lost much of its significance. In the 1980s, almost $7 \%$ of the Social Democratic Party's appeals targeted women or men (women 5\%, men 2\%). Yet, in the 2000s, the percentages were down to $1.3 \%$ for women and less than $0.5 \%$ for men. Further, even if an education cleavage has emerged in Danish politics (Stubager 2013), groups denoting educational attainment have not become particularly salient over time. The highly educated, low-educated or other similar terms are rarely used in party programs. As the results show, the low-educated was targeted from the 1980s onward, but the percentage is only around $0.5 \%$, and the highly educated are not mentioned at all during the period studied. On the other hand, and unsurprising seeing how the issue agenda has changed in Denmark (Andersen and Borre 2003), immigrants went from not being referenced in the 1960s to being targeted in 3\% of the Social Democratic Party's appeals in the 1980s. In the 2000s, the percentage decreased slightly, but immigrants now seem to be a common target group.

Third, Table 3 shows how a number of group categories that comparative political research has not yet focused on constitute target groups of increasing importance, at least for the Social Democratic Party in Denmark. For example, children has emerged as the most prominent target group over the period studied. 
In the 2000s, more than $13 \%$ of all group-based appeals made by the Social Democratic Party targeted children, which means that the salience of this category has tripled since the 1960s. Young people (5\%), the elderly (5\%) and the ill (4\%) were also among the prominent target groups in the 2000s, with their salience increasing steadily over the years. This suggests that current research is overlooking a number of group categories that may play a substantial role in party electoral strategies. The emergence of these target groups is undoubtedly tied to the increasing salience of welfare issues such as health, childcare, education and eldercare in Denmark and Western Europe in general (e.g. Green-Pedersen 2011).

In sum, the development in the non-economic group-based appeals shows that the Social Democratic Party has always found it important to target broad and inclusive groups, contrary to how social democratic party strategies have sometimes been described (Przeworski 1985). At the same time, well-theorized cleavages based on place, gender or religion have not replaced class in the Social Democratic Party's electoral strategy. Instead, this party has increasingly been targeting what we could call welfare groups, which have become much more politicized in Danish politics in recent decades.

\section{Conclusion}

Many studies now suggest that the mobilization strategies of social democratic parties were key in the decline of class politics. Adopting a group perspective on class demobilization, and based on a new content analysis of party platforms, this article has analyzed how the Social Democratic Party in Denmark has changed its group-based appeals from 1961 to 2004.

The results show a diminishing salience of the working class, as well as economic groups more generally, between 1961 and 2004. The most striking change is that the Social Democratic Party increasingly targets non-economic groups such as children, elderly people and the ill at the expense of economic group categories. And while low-income people, wage earners, and other groups belonging to the left-wing base have lost emphasis in the group-based appeals of the Social Democratic Party, middle-class professions and businesses - the counterparts of the working class - have been relatively stable target groups. In fact, the Social Democratic Party has become increasingly likely to associate itself with businesses, in contrast to previous times where the party often distanced itself from businesses. This all suggests that the Social Democratic Party adjusted its mobilization strategy in the face of changing voter priorities and a declining working class with the goal of becoming a catch-all party (Przeworski and Sprague 1986; Kitschelt 1994). 
This article has shown that a group perspective can help us better understand the demobilization of class politics. However, it only represents the first step. The next step should be to test empirically whether social democratic parties have actually influenced class voting by downplaying their working class image, as expected. Denmark, and other countries that deviate from the policy-centered theoretical model, would be ideal test cases.

Another question remaining is whether social democratic parties in other countries have changed their group-based appeals in the same way as the Social Democratic Party in Denmark. We should expect so given that social democratic parties in other Western Europe countries have faced similar electoral changes (see Thau 2017 for evidence on Britain). On the other hand, Denmark also differs from other countries in terms of its extensive and institutionalized welfare provision, which could make it less costly for the social democratic party to downplay its class image than would be the case outside Scandinavia.

A final question is what role other political parties may play? This article has focused on the Social Democratic Party because the literature ascribes social democratic parties a major role. Yet, both in relation to the strategy of social democratic parties and to the expected effects on class voting, other party actors might play a role, too. For example, a classic argument is that right-wing parties can undermine the working class support of social democratic parties by politicizing and mobilizing group identities that are not based on social class (Lipset 1981). Thus, the group perspective advanced here not only sheds new light on class demobilization but also points to a broader research agenda for future research on class politics and electoral change.

\section{Supplementary Material}

Additional material for the article is available in Danish at www.politica.dk.

\section{References}

Achen, Christopher and Larry Bartels (2016) Democracy for Realists: Why Elections Do Not Produce Responsive Government. Princeton, N): Princeton University Press.

Andersen, Jørgen Goul and Ole Borre (2003) Politisk forandring. Værdipolitik og nye skillelinjer ved folketingsvalget 2001. Aarhus: Systime.

Bartolini, Stefan and Peter Mair (1990) Identity, Competition, and Electoral Availability: The Stability of European Electorates, 1885-1985. Cambridge: Cambridge University Press. Best, Robin (2011) “The Declining Electoral Relevance of Traditional Cleavage Groups," European Political Science Review, 3:279-300. 
Brooks, Clem, Paul Nieuwbeerta and Jeff Manza (2006) "Cleavage-Based Voting Behavior in Cross-National Perspective: Evidence from Six Postwar Democracies,” Social Science Research, 35:88-128.

Budge, Ian and Dennis Farlie (1983) "Party Competition: Selective Emphasis or Direct Confrontation? An Alternative View with Data." In: (Hans Daalder and Peter Mair, red.) Western European Party Systems. Continuity \& Change. Beverly Hills: Sage, pp. 267-305.

Budge, Ian, Hans-Dieter Klingemann, Andrea Volkens, Judith Bara and Eric Tanenbaum (2001) Mapping Policy Preferences. Estimates for Parties, Electors, and Governments 1945-1998. Oxford: Oxford University Press.

Butler, David and Donald Stokes (1969) Political Change in Britain. The Evolution of Electoral Choice. London: Palgrave Macmillan.

Campbell, Angus, Philip Converse, Warren Miller and Donald Stokes (1960) The American Voter. New York: Wiley.

Conover, Pamela (1988) “The Role of Social Groups in Political Thinking," British Journal of Political Science, 18(1):51-76.

Converse, Phillip (1964) “The Nature of Belief Systems in Mass Publics.” In: (i David Apter, red.) Ideology and Discontend. New York: The Free Press, pp. 206-261.

Crouch, Colin (2008) "Change in European Societies since the 1970s," West European Politics, 31(1-2):1-14.

Dalton, Russel (2014) Citizen Politics: Public Opinion and Political Parties in Advanced Industrial Democracies, 6th ed. Chatnam, NJ: Chatnam House.

Dalton, Russel and Martin Wattenberg (1993) "The not so Simple Act of Voting." In: (i Ada Finifter, red.) Political Science: The State of the Discipline II. American Political Science Association, pp. 193-218.

Elff, Martin (2009) “Social Divisions, Party Positions and Electoral Behaviour," Electoral Studies, 28:297-308.

Evans, Geoffrey (2000) “The Continued Significance of Class Voting,” Annual Review of Political Science, 3:401-417.

Evans, Geoffrey and James Tilley (2012) "How Parties Shape Class Politics: Explaining the Decline of the Class Basis of Party Support," British Journal of Political Science, 42(1):137-161.

Evans, Geoffrey and Nan Dirk de Graaf (2013) Political Choice Matters: Explaining the Strength of Class and Religious Cleavages in Cross-National Perspective. Oxford: Oxford University Press.

Evans, Geoffrey and James Tilley (2017) The New Politics of Class in Britain: The Political Exclusion of the Working Class. Oxford: Oxford University Press.

Franklin, Mark, Thomas Mackie and Henry Valen (1992) Electoral Change. Responses to Evolving Social and Attitudinal Structures in Western Countries. Cambridge: Cambridge University Press.

Green-Pedersen, Christoffer (2006) “Long-Term Changes in Danish Party Politics: The Rise and Importance of Issue Competition," Scandinavian Political Studies, 29(3):219-235.

Green-Pedersen, Christoffer (2011) Partier i nye tider: Den politiske dagsorden i Danmark. Aarhus: Aarhus Universitetsforlag.

Hansen, Martin Ejnar (2008) "Back to the Archives? A Critique of the Danish Part of the Manifesto Dataset," Scandinavian Political Studies, 31(2):201-216.

Harrits, Gitte Sommer (2014) Klasse. En introduktion. København: Hans Reitzels Forlag. Heath, Oliver (2015) "Policy Representation, Social Representation and Class Voting in Britain," British Journal of Political Science, 45(1):173-193. 
Helbling, Marc and Anke Tresch (2011) "Measuring Party Positions and Issue Salience from Media Coverage: Discussing and Cross-Validating New Indicators," Electoral Studies 30(1):174-183.

Hjort, Frederik (2017) “Emneejerskab - hvilke partier ejer hvilke emner?” In: (i Kasper Møller Hansen and Rune Stubager, red.) Oprør fra udkanten. København: Jurist- og Økonomiforbundets Forlag, pp. 193-205.

Hobolt, Sara (2013) “Enduring Divisions and New Dimensions." In: (Geoffrey Evans and Nan Dirk de Graaf, red.) Political Choice Matters: Explaining the Strength of Class and Religious Cleavages in Cross-National Perspective. Oxford: Oxford University Press, pp. 185-204.

Hout, Michael (2008) "How Class Works: Objective and Subjective Aspects of Class since the 1970s." In: (Annette Lareau and Dalton Conley, red.) Social Class. How Does it Work? New York, NY: Russell Sage Foundation, pp. 25-64.

Inglehart, Ronald (1997) Modernization and Post-modernization: Cultural, Economic, and Political Change in 43 Societies. Princeton, NJ: Princeton University Press.

Kinder, Donald (1998) “Communication and Opinion,” Annual Review of Political Science, 1:167-197.

Kinder, Donald and Cindy Kam (2009) Us Against Them: Ethnocentric Foundations of American Opinion. Chicago: University of Chicago Press.

Kirchheimer, Otto (1966) “The Transformation of the Western European Party Systems.” In: (Joseph LaPalombera and Myron Weiner, red.) Political Parties and Political Development. Princeton, NJ: Princeton University Press, pp. 177-200.

Kitschelt, Herbert (1994) The Transformation of European Social Democracy. Cambridge: Cambridge University Press.

Knutsen, Oddbjørn (2006) Class Voting in Western Europe: A Comparative Longitudinal Study. Oxford: Lexington Books.

Knutsen, Oddbjørn (2007) “The Decline of Social Class?” In: (Russell Dalton and Hans-Dieter Klingemann, red.) Oxford Handbook of Political Science. Oxford: Oxford University Press, pp. 457-480.

Kosiara-Pedersen, Karina and Lars Bille (2004) "Electoral Fortunes and Responses of the Social Democratic Party and Liberal Party in Denmark: Ups and Downs.” In: (Fritz Plasser, Wolfgang Müller and Peter Mair, red.) Political Parties and Electoral Change: Party Responses to Electoral Markets. London: Sage, pp. 207-233.

Kriesi, Hanspeter, Edgar Grande, Romain Lachat, Martin Dolezal, Simon Bornschier and Timotheos Frey (2008) West European Politics in the Age of Globalization. Cambridge: Cambridge University Press.

Krippendorff, Klaus (2004) Content Analysis: An Introduction to its Methodology. London: Sage. Lipset, Seymour Martin (1981) Political Man. The Social Bases of Politics, 2nd ed. Baltimore: Johns Hopkins University Press.

Lipset, Seymour Martin and Stein Rokkan (1967) Party Systems and Voter Alignments: CrossNational Perspectives. New York: The Free Press.

Mair, Peter (2013) Ruling the Void: The Hollowing of Western Democracy. London: Verso.

Miller, Arthur, Christopher Wlezien and Anne Hildreth (1991) "A Reference Group Theory of Partisan Coalitions," The Journal of Politics, 53(4):1134-1149.

Nelson, Thomas and Donald Kinder (1996) "Issue Frames and Group-Centrism in American Public Opinion," Journal of Politics, 58:1055-1078.

Oskarson, Maria (2005) "Social Structure and Party Choice." In: (i Jacques Thomassen, red.) The European Voter. A Comparative Study of Modern Democracies. Oxford: Oxford University Press, pp. 84-105. 
Popkin, Samuel (1994) The Reasoning Voter: Communication and Persuasion in Presidential Campaigns. Chicago: University of Chicago Press.

Przeworski, Adam (1985) Capitalism and Social Democracy. Cambridge: Cambridge University Press.

Przeworski, Adam and John Sprague (1986) Paper Stones: A History of Electoral Socialism. Chicago: University of Chicago Press.

Sartori, Giovanni (1997) “The Sociology of Parties: A Critical Review.” ch. 11 In: (Peter Mair, red.) The West European Party System. Oxford: Oxford University Press.

Seawright, Jason and John Gerring (2008) "Case Selection Techniques in Case Study Research: A Menu of Qualitative and Quantitative Options," Political Research Quarterly, 61(2):294-308.

Stubager, Rune (2009) “Hvem repræsenterer partierne?” In: (Jens Blom-Hansen, Jørgen Elklit, red.) Perspektiver på politik: Bidrag til samfundsdebatten. Aarhus: Systime Academic, pp. 38-43.

Stubager, Rune (2013) "The Changing Basis of Party Competition: Education, AuthoritarianLibertarian Values and Voting," Government and Opposition, 48:372-397.

Thau, Mads (2017) "How Political Parties Use Group-Based Appeals: Evidence from Britain, 1964-2015,” Political Studies, doi: 10.1177/0032321717744495. 